\title{
The Evolution of Retinopathy of Prematurity Publications: A Holistic Investigation of Global Outputs with Bibliometric Analysis
}

\section{Prematüre Retinopatisi Yayınlarının Değerlendirmesi: Bibliyometrik Analiz ile Küresel Çıktıların Bütünsel Bir İncelemesi}

\section{(D) Özge Begüm Comba}

Yeni Yüzyıl University Gaziosmanpaşa Hospital, Clinic of Ophthalmology, İstanbul, Turkey

\begin{abstract}
Objective: Although retinopathy of prematurity (ROP) affects preterm newborns at a significant rate worldwide, no comprehensive bibliometric research has been conducted as yet. This study aimed to use bibliometric methods to present a summary of articles published on ROP between 1980 and 2019 , to identify the articles most cited in the field, most active journals, and subjects of trends. Using the bibliometric analysis, readers were introduced to the articles published on ROP as a whole. The results of the study will be of guidance to researchers in terms of which subjects require more research and what subjects of new research could be.

Method: Articles published on ROP between 1980 and 2019 were downloaded from the Web of Science database and analyzed with bibliometric methods. The literature scan was made using the following keywords: "retinopathy of prematurity," "retrolental fibroplasia," and "ROP" in the title section. The correlations between the number of publications in a country and gross domestic product (GDP) and GDP per capita values were analyzed using Spearman's correlation coefficient. The number of articles to be published in the future was estimated with linear regression analysis.

Results: 4,575 publications on ROP were identified, of which 2,345 were articles. A continuing increasing trend for publication was seen. The five countries producing the most articles on ROP were as follows: USA (978), UK (187), Turkey (156), India (140), and China (121). A statistically significant positive correlation was determined between the number of ROP articles produced and the GDP and GDP per capita values of countries $(r=0.688, p<0.001 ; r=0.664, p<0.001)$. Journals publishing the most articles were the Journal of American Association for Pediatric Ophthalmology and Strabismus, Ophthalmology, and British Journal of Ophthalmology, respectively. The most cited area was the international classification of premature retinopathy.

Conclusion: In parallel with the increasing importance of ROP, this comprehensive study, evaluating articles in this field as a whole, will be of guidance to clinicians, academicians, and students interested in this subject.

Keywords: Retinopathy of prematurity, ROP, retrolental fibroplasia, bibliometrics, scientometrics

\section{öz}

Amaç: Prematüre retinopatisi (ROP) dünya genelinde önemli miktarda preterm yenidoğanı etkileyen önemli bir konu olmasına rağmen bu konuda henüz kapsamlı bir bibliyometrik araștırma yapılmamıștır. Bu çalıșmanın amacı bibliyometrik yöntemlerle ROP konusunda 1980-2019 yılları arasında yayınlanan makalelerin bütünsel bir özetini sunmak, alandaki en çok atıf yapılan makaleleri belirlemek, en aktif dergileri ve trend konularını belirlemektir. Yaptığımız bibliyometrik analiz ile ROP konusundaki yayınları bir bütün olarak okuyuculara göstermeyi amaçladık. Bu çalıșmanın sonuçları ayrıca hangi konuların daha fazla çalıșılmaya intiyaç duyduğu ve hangi yeni araștırma konularının olabileceği konusunda araștırmacılara fikir sağlayacaktır.
\end{abstract}

Cite as: Comba ÖB. The Evolution of Retinopathy of Prematurity Publications: A Holistic Investigation of Global Outputs with Bibliometric Analysis. IKSSTD 2021;13(2):104-15

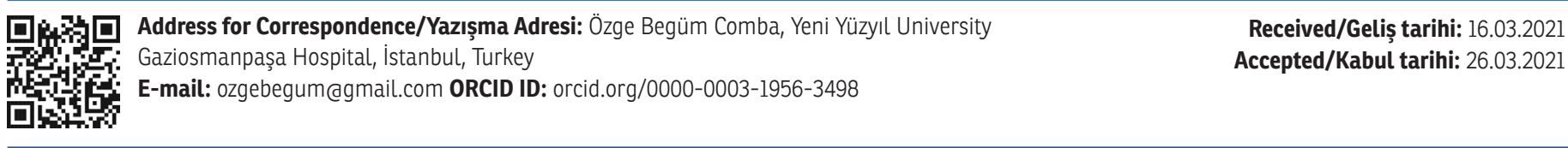

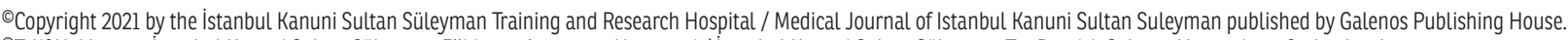
๑Telif Hakkı 2021 İstanbul Kanuni Sultan Süleyman Eğitim ve Araștırma Hastanesi / İstanbul Kanuni Sultan Süleyman Tıp Dergisi, Galenos Yayınevi tarafindan basılmışıır. 
Yöntem: ROP konusunda 1980 ve 2019 yılları arasında yayınlanan makaleler Web of Science veritabanından indirildi ve bibliyometrik yöntemler kullanılarak analiz edildi. Literatür taraması makalelerin "title" bölümünde "retinopathy of prematurity", "retrolental fibroplasia" "ROP" anahtar kelimeleri kullanılarak gerçekleștirildi. Ülkelerin yayın sayısı ile Gayri Safi Yurtiçi Hasıla (GSYH) ile kiși bașına GSHY değerleri arasındaki korelasyonlar Spearman'ın korelasyon katsayısı kullanılarak analiz edildi. Gelecekte yayınlanacak makale sayısı doğrusal regresyon analizi ile tahmin edildi.

Bulgular: ROP konusunda toplam 4.575 yayın bulundu. Bu yayınların 2.345'i makale idi. ROP konusunda her geçen gün artan bir yayın trendi olduğu görüldü. ROP konusunda en fazla makale üreten ilk 5 ülke sırasılyla USA (978), UK (187), Turkey (156), India (140), ve China (121) idi. Dünya ülkelerinin GSYH ve GSYH göstergeleri ile ROP yayın üretkenlikleri arasında istatistiksel olarak anlamlı pozitif bir korelasyon bulundu ( $r=0,688, p<0,001 ; r=0,664, p<0,001)$. En fazla yayın üreten dergiler sırasıly Journal of AAPOS, Ophthalmology, ve British Journal of Ophthalmology idi. Makale bașına atıfta en etkili dergiler Pediatrics, Archives of Ophthalmology, ve Ophthalmology idi. Prematüre retinopatisinin uluslararası sınflandırması en fazla atıf alan konu idi.

Sonuç: ROP'nin artan önemine paralel olarak, bu alandaki makalelerin bütüncül bir değerlendirmesini yapan bu kapsamlı çalısma, bu konuya ilgi duyan doktor, akademisyen ve öğrencilere yön gösterecektir.

Anahtar kelimeler: Retinopathy of prematurity, ROP, retrolental fibroplasia, bibliometrics, scientometrics

\section{INTRODUCTION}

Retinopathy of prematurity (ROP) is an important eye disease that occurs in premature infants and affects vision at a significant rate ${ }^{(1-3)}$. Retinopathy is one of the leading preventable causes of blindness ${ }^{(4)}$.

The incidence of ROP shows variability according to the level of development of countries and characteristics of neonatal intensive care units (NICU). In a retrospective study by Sancak et al. ${ }^{(5)}$, ROP frequency at the end of a fouryear period (2011-2014) was $43 \%$ in 888 preterm newborns [gestational age $(G A) \leq 32$ weeks and birth weight $\leq 1500 \mathrm{~g}$, followed up in NICU. In a multicenter prevalence study by Bas et al. ${ }^{(6)}$ (2018), 27\% ROP and 6.7\% severe ROP were determined at any stage in 6115 infants [4964 (81\%) with GA $\leq 32$ weeks and 1151 (19\%) with GA > 32 weeks] in 69 NICU. Eriș et al. ${ }^{(7)}$ (2018) reported ROP at a rate of $41.7 \%$ in infants with a birth weight less than $1500 \mathrm{~g}$ and $27 \%$ in infants of GA less than 34 weeks. A prospective study in Sweden reported ROP (at any stage) at a rate of $73 \%(368 / 506)$ and severe retinopathy at a rate of $35 \%(175 / 506)$ in infants with GA less than 27 weeks ${ }^{(8)}$. Another study in Austria reported severe ROP in 16\% (50/316) of infants with GA less than 27 weeks ${ }^{(9)}$.

Bibliometric analyses are the statistical and mathematical analyses of publications, such as books and articles, produced by an institution or country in a specific area of research ${ }^{(10-13)}$. The aim of bibliometric studies is to analyze the increasing rate and development of studies in a specific area or discipline, summarize literature, and evaluate the current status of scientific publication policies of a country $(14,15)$. Bibliometric studies allow comparisons between countries, institutions, or authors on various subjects $(4,16,17)$.

In parallel with the technological developments and improvements in neonatal care, the increase in survival rates of preterm newborns with a lower GA led to an increase in the frequency of ROP, which continues to be a significant problem. Although ROP affects preterm newborns at a significant rate, no comprehensive bibliometric study on the subject has been conducted to date. This study aimed to use bibliometric methods to present a summary of articles published on ROP between 1980 and 2019 and identify the articles most cited in the field, the most active journals, and subjects of trends. With this bibliometric analysis, readers are introduced to the articles published on ROP as a whole. The results of the study will be of guidance to researchers in terms of which subjects require more research and what subjects of new research could be.

\section{METHOD}

Articles published on ROP between 1980 and 2019 were downloaded from the Web of Science database (WoS; Web of Science by Clarivate Analytics) and analyzed with bibliometric methods. The literature scan was made using the keywords in the "title" section as follows: "retinopathy of prematurity," "retrolental fibroplasia" (in all research areas), and "ROP" (only in ophthalmology and pediatrics research areas because ROP is used with different meanings such as ring-opening polymerization in different research areas). (\#1: Title: ("retinopathy of prematurity"), \#2: Title: ("retrolental fibroplasia"), \#3: Title: ("ROP") refined by: WoS Categories: (Ophthalmology or Pediatrics). \#1 OR \#2 OR \#3 Timespan: 1975-2019. Indexes: SCI-Expanded, SSCl, A\&HCI, CPCI-S, CPCl-SSH, BKCl-S, BKCl-SSH, ESCI).

\section{Statistical Anaysis}

This research method included all articles published on this subject. Bibliometric analyses were performed using VOSviewer (Version 1.6.13) software. The correlations between the number of publications in a country and gross domestic 
product (GDP) and GDP per capita (purchasing power parity, GDP PPP) values were analyzed using Spearman's correlation coefficient. Spearman's correlation coefficient was evaluated as follows: $0.90-1.00$ was considered very high; 0.70-0.89, high; 0.50-0.69, moderate; 0.26-0.49, low. The number of articles to be published in the period 2019-2024 was estimated using linear regression analysis. Statistical analyses were performed using SPSS version 22.0 software (SPSS Inc., Chicago, IL, USA). A value of $p<0.05$ was considered statistically significant.

\section{RESULTS}

Based on the literature scan, 4,575 publications on ROP were identified. Of these, $51.25 \%(n=2345)$ were articles, $26.49 \%$ $(n=1212)$, meeting abstracts, $9.73 \%(n=445)$, letters, $5.83 \%$ (267), proceedings papers, 5.29\% (242), editorial materials, and $3.45 \%$ (158), reviews, and the remaining (79) were other types of publication (correction, book chapter, note, early access, book review, discussion, correction addition, news item, reprint, retracted publication).

Of the 2345 published articles, $96.162 \%(n=2255)$ were in English and the remaining were in other languages: German (44), Spanish (15), French (13), Portuguese (6), Turkish (4), Korean (3), Italian (2), Polish (1), and Slovenian (1).

Two thousand three hundred and forty-five (2345) articles received 52,141 citations (without self-citations: 26,018), and the mean number of article title citations was 22.23 . The total h-index of the articles was 86.

\section{Research Areas}

Of the total articles, $67.80 \%(n=1590)$ were published in the field of ophthalmology, followed by pediatrics (670; $28.57 \%)$, general internal medicine (112; 4.77\%), obstetrics gynecology (112; 4.77\%), research experimental medicine (64; $2.72 \%)$, surgery $(56 ; 2.38 \%)$, biochemistry molecular biology $(37 ; 1.57 \%)$, science technology and other topics (36; $1.53 \%)$, cell biology $(19 ; 0.81 \%)$, and neurosciences neurology (14;0.59\%).

\section{Development of Publications}

The distribution of the articles by year is shown in Figure 1. According to the regression analysis, it was estimated that 181 articles would be published in 2020 [95\% confidence interval (Cl): 159-203] and 246 in 2025 (95\% Cl: 199-293). The other results are shown in Figure 1.

\section{Active Countries and Correlation Analysis}

The leading 15 countries producing the most articles on ROP were determined to be the USA (978), UK (187), Turkey (156), India (140), China (121), Germany (96), Canada (84), Japan (81), Sweden (76), Australia (75), Italy (48), South Korea (48), Taiwan (48), Brazil (41), and Iran (41). Countries producing publications on ROP are shown in Figure 2.

A statistically significant positive correlation was determined between the number of ROP articles and GDP and GDP PPP values of countries $(r=0.688, p<0.001 ; r=$ $0.664, p<0.001)$.

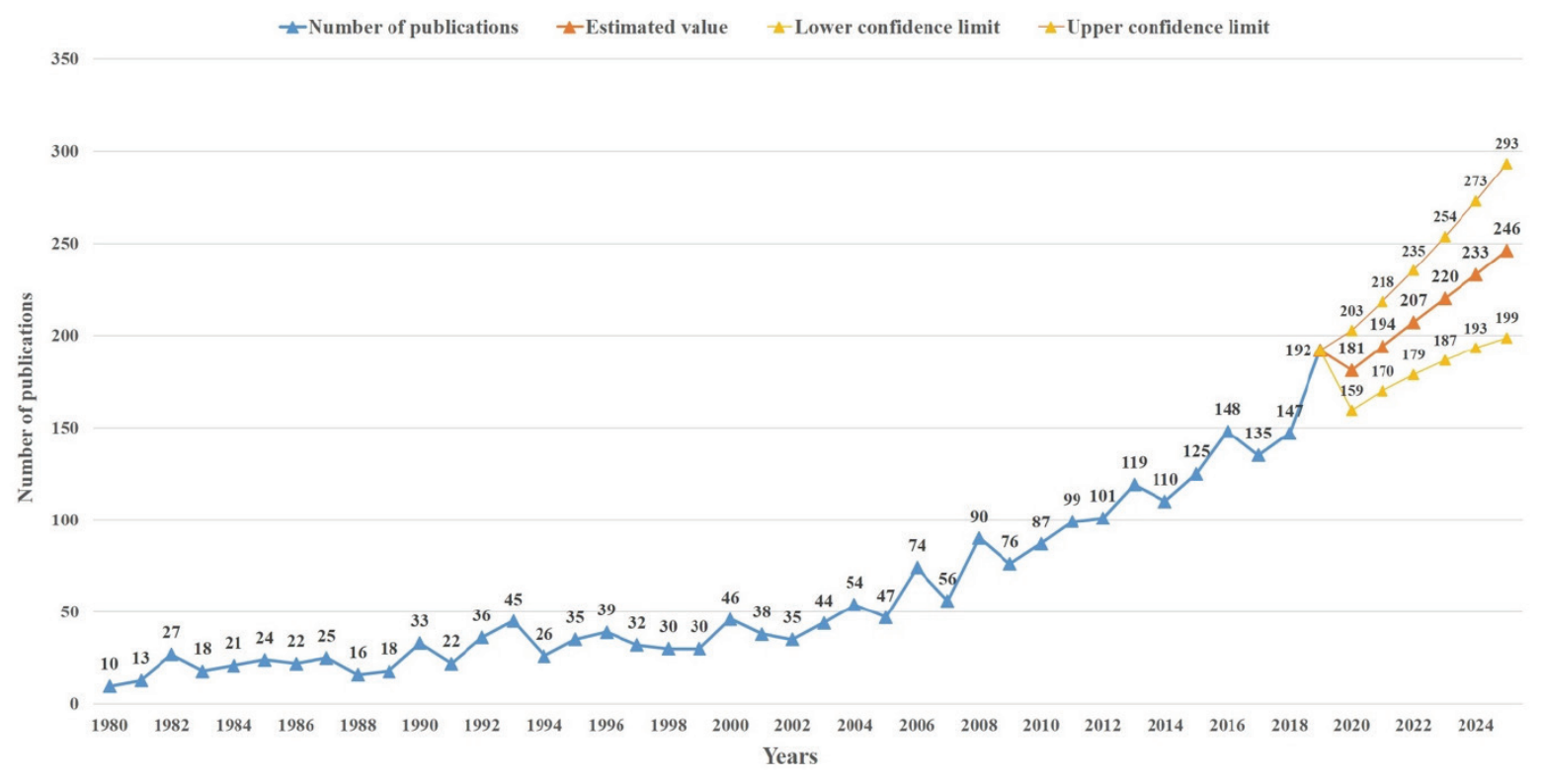

Figure 1. Number of publications by year on the topic of retinopathy of prematurity 


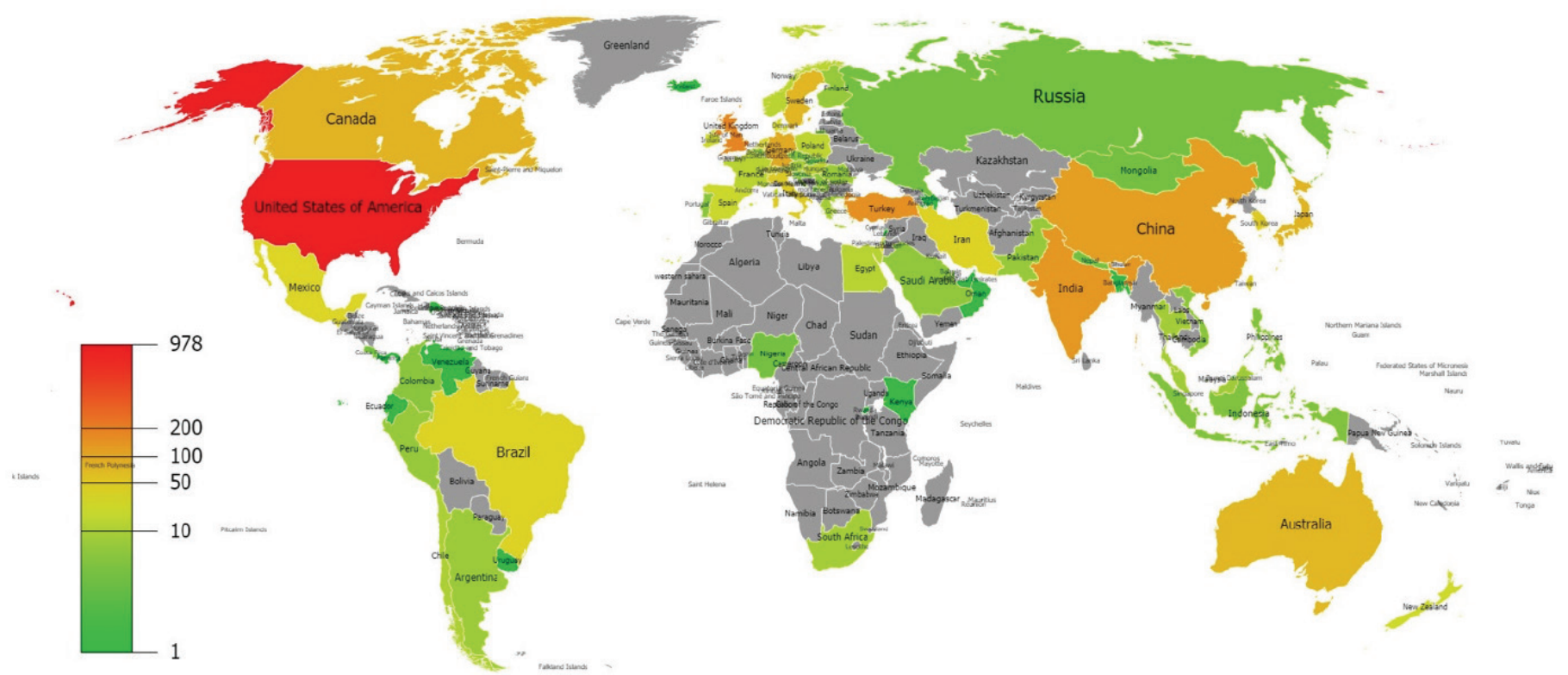

Figure 2. World map for the publication productivity of worldwide countries on the topic of retinopathy of prematurity. Footnote: In the indicator given at the bottom left of the figure, productivity increases from green to red

Eighty-one countries produced articles on ROP. The international collaboration network visualization map between the 44 countries that produced at least five articles is shown in Figure 3.

\section{Active Authors}

The authors who produced the most publications on ROP were Quinn GE. ( $n=98$ ), Chiang MF (59), Tung B. (49), Trese MT. (47), Palmer EA. (46), Hellstrom A. (44), Dobson V. (43), Capone A. (42), Hardy RJ. (41), and Hartnett ME. (41).

\section{Active Organization}

The organizations most productive on the subject of ROP and organizations-enhanced are shown in Table 1.

\section{Active Journals}

Three hundred and fifty-one journals had publications on ROP. The leading 40 journals publishing the most articles on this subject are shown in Table 2. The total number of citations received by the ROP articles in the journals is shown in the last column of Table 2. The citation network visualization map between these journals is shown in Figure 4 .

\section{Citation Analysis}

The 20 articles receiving the most citations are shown in Table 3. The mean number of citations received by the articles per year is shown in the last column of Table 3.

\section{Cocitation Analysis}

A total of 19,731 publications were cited in the references of 2,345 articles. The cocitation density map between the 73 articles cited at least 60 times is shown in Figure 5. The five articles with the most cocitations were Good, 2003, with 647 citations, Gole, 2005, with 559 citations, Garner, 1984, with 422 citations, Palmer, 1988, with 309 citations, and Palmer, 1991 with 302 citations (17-21).

\section{Trend Topics}

A total of 1850 keywords were used in 2345 articles. Of these keywords, 74, which were used in at least eight articles, were subjected to cluster analysis (Table 4). The network maps related to the results, trend word analysis, and citation analysis are shown in Figures 6, 7, and 8, respectively.

\section{DISCUSSION}

When the results of the bibliometric analysis were evaluated, a continuously increasing trend for publications on ROP was observed. Ten to fifty articles were published each year in the period of 1980-2003, 50-100 articles between 2004 and 2011, more than 100 articles between 2012 and 2019, and recently, almost 200 articles. This increase was confirmed in the regression analysis results, which showed that there could be an increasing trend in the number of articles. 


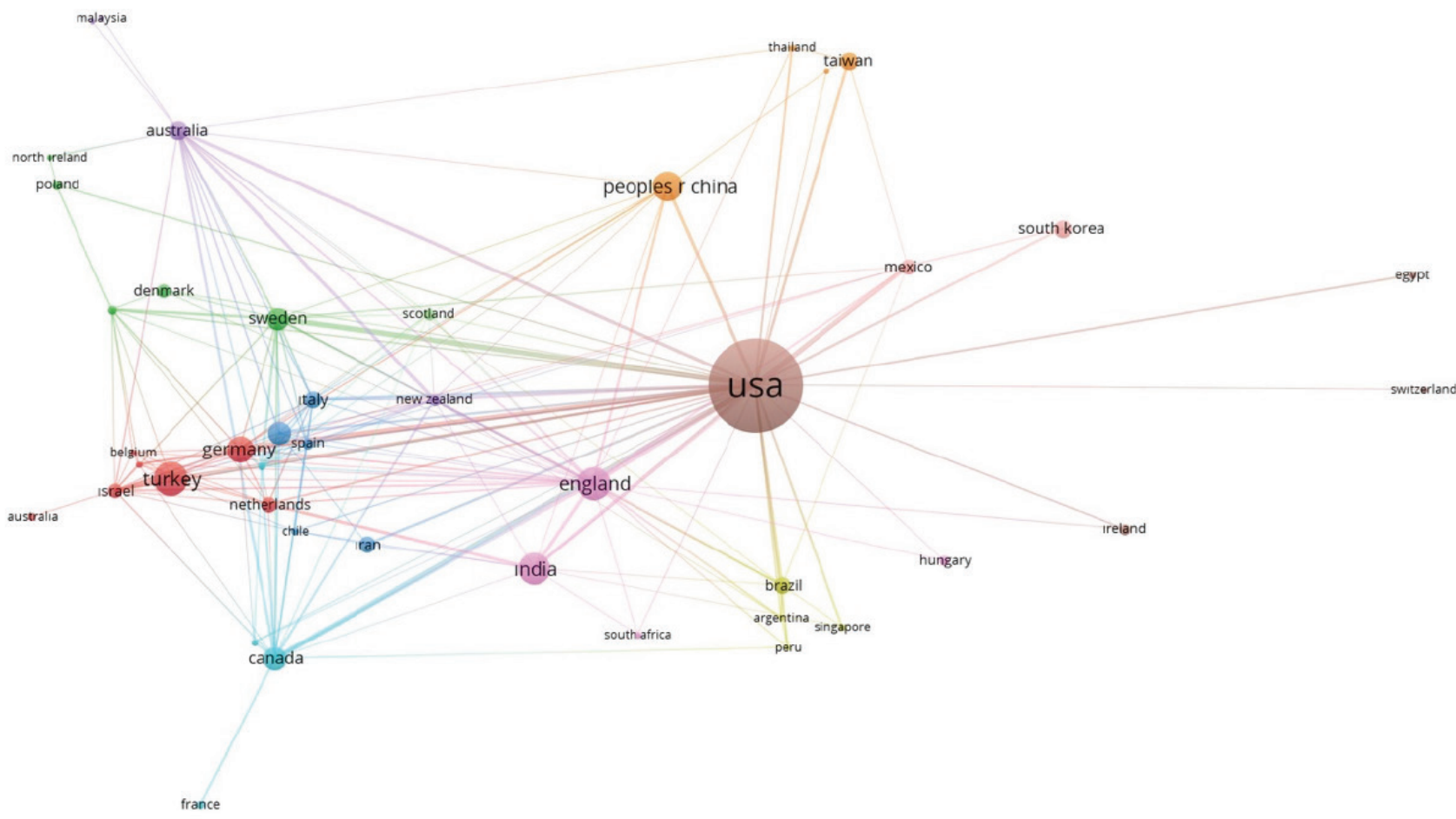

jo vosviewer

Figure 3. Network visualization map for international collaboration of worldwide countries on the topic of retinopathy of prematurity. Footnote: The size of the circle shows the large number of publications, the colors indicate the cluster of collaboration, and the thickness of the lines indicates the strength of collaboration

Table 1. Active organization and organizations-enhanced searches on retinopathy of prematurity

\begin{tabular}{|l|l|l|l|}
\hline Organization & RC & Organization-enhanced & RC \\
\hline Harvard University & 132 & University of Pennsylvania & 91 \\
\hline University of Pennsylvania & 121 & Harvard University & 81 \\
\hline Children's Hospital of Philadelphia & $11 l$ & Oregon Health \& Science University & 81 \\
\hline University of Texas System & 87 & Children's Hospital of Philadelphia & 75 \\
\hline Boston Children's Hospital & 86 & Duke University & 61 \\
\hline Oregon Health Science University & 81 & Children's Hospitals & 56 \\
\hline Duke University & 68 & University of Texas & 44 \\
\hline University of California System & 61 & William Beaumont Hospital & 44 \\
\hline University of Texas Health Science Center at Houston & 60 & University of North Carolina & 42 \\
\hline University of London & 54 & University of Gothenburg & 41 \\
\hline Baylor College of Medicine & 50 & Baylor College of Medicine & 40 \\
\hline Beaumont Health & 48 & University of Illinois & 39 \\
\hline University of Texas School Public Health & 46 & University of Utah & 33 \\
\hline Johns Hopkins University & 45 & Stanford University & 32 \\
\hline University of Gothenburg & 45 & University of Miami & 31 \\
\hline RC: Record count & & & \\
\hline
\end{tabular}




\begin{tabular}{|c|c|c|c|c|c|c|c|}
\hline Journal & $\mathrm{RC}$ & C & AC & Journal & $\mathrm{RC}$ & C & $A C$ \\
\hline Journal of AAPOS & 138 & 2282 & 16.5 & Acta Ophthalmologica Scandinavica & 22 & 461 & 21.0 \\
\hline Ophthalmology & 129 & 5414 & 42.0 & Documenta Ophthalmologica & 21 & 211 & 10.0 \\
\hline British Journal of Ophthalmology & 118 & 3001 & 25.4 & Journal of Pediatrics & 21 & 607 & 28.9 \\
\hline Archives of Ophthalmology & 116 & 8137 & 70.1 & Current Eye Research & 20 & 202 & 10.1 \\
\hline Investigative Ophthalmology Visual Science & 95 & 2891 & 30.4 & Ophthalmologe & 20 & 67 & 3.4 \\
\hline $\begin{array}{l}\text { Journal of Pediatric Ophthalmology } \\
\text { Strabismus }\end{array}$ & 92 & 817 & 8.9 & $\begin{array}{l}\text { Archives of Disease in Childhood Fetal and } \\
\text { Neonatal Edition }\end{array}$ & 19 & 422 & 22.2 \\
\hline $\begin{array}{l}\text { Retina, The Journal of Retinal and Vitreous } \\
\text { Diseases }\end{array}$ & 82 & 1887 & 23.0 & $\begin{array}{l}\text { Canadian Journal of Ophthalmology } \\
\text { Journal (Canadien D'Ophtalmologie) }\end{array}$ & 19 & 192 & 10.1 \\
\hline American Journal of Ophthalmology & 79 & 1811 & 22.9 & International Ophthalmology & 19 & 75 & 3.9 \\
\hline Pediatrics & 65 & 5329 & 82.0 & Pediatric Research & 19 & 611 & 32.2 \\
\hline Eye & 62 & 1052 & 17.0 & PLOS One & 19 & 232 & 12.2 \\
\hline $\begin{array}{l}\text { Graefe's Archive for Clinical and } \\
\text { Experimental Ophthalmology }\end{array}$ & 56 & 963 & 17.2 & Japanese Journal of Ophthalmology & 17 & 114 & 6.7 \\
\hline Indian Journal of Ophthalmology & 48 & 213 & 4.4 & Journal of Ophthalmology & 17 & 66 & 3.9 \\
\hline Acta Ophthalmologica & 41 & 409 & 10.0 & $\begin{array}{l}\text { Klinische Monatsblatter Fur } \\
\text { Augenheilkunde }\end{array}$ & 17 & 52 & 3.1 \\
\hline Jama Ophthalmology & 33 & 501 & 15.2 & Arquivos Brasileiros De Oftalmologia & 16 & 73 & 4.6 \\
\hline $\begin{array}{l}\text { Ophthalmic Surgery, Lasers and Imaging } \\
\text { Retina }\end{array}$ & 32 & 198 & 6.2 & Molecular Vision & 16 & 491 & 30.7 \\
\hline Journal of Perinatology & 31 & 391 & 12.6 & Neonatology & 16 & 252 & 15.8 \\
\hline Acta Paediatrica & 27 & 400 & 14.8 & BMC Ophthalmology & 15 & 54 & 3.6 \\
\hline European Journal of Ophthalmology & 26 & 230 & 8.8 & Ophthalmologica & 15 & 212 & 14.1 \\
\hline Early Human Development & 25 & 983 & 39.3 & Clinical and Experimental Ophthalmology & 14 & 196 & 14.0 \\
\hline International Journal of Ophthalmology & 24 & 61 & 2.5 & Clinics in Perinatology & 14 & 292 & 20.9 \\
\hline
\end{tabular}

On studying the countries producing publications on ROP, it was shown that countries that had a strong economy, such as the USA, UK, China, Germany, Canada, Japan, Sweden, Australia, Italy, South Korea, and Taiwan, had effective publications on this subject. However, the contribution of developing countries to this subject is noticeable, with Turkey and India as the third and fourth countries producing the most publications. Moreover, Brazil and Iran were among the 15 leading countries producing the most publications. Several studies in the literature have shown that the development and economic strength of a country are determinants of publication productivity ${ }^{(10,12-14)}$. The findings of the current study are parallel with those results. The significant correlation found between the economic indicators and production of publications confirmed this result. When the common authorship results between countries were examined, an effective collaboration of geographical regions was observed.
The most active journals publishing more than 100 articles were the Journal of American Association for Pediatric Ophthalmology and Strabismus (AAPOS), Ophthalmology, British Journal of Ophthalmology, and Archives of Ophthalmology, respectively. The journals receiving the most citations in total were determined to be the Archives of Ophthalmology, Ophthalmology, Pediatrics, British Journal of Ophthalmology, Investigative Ophthalmology Visual Science, and Journal of AAPOS. The journals receiving the most citations per article were Pediatrics, Archives of Ophthalmology, Ophthalmology, Early Human Development, Pediatric Research, Investigative Ophthalmology Visual Science, Molecular Vision, and Investigative Ophthalmology Visual Science. Submission of articles for evaluation by these journals can be recommended to researchers of this subject.

According to the total and mean numbers of citations, the most effective study was "The International Classification of Retinopathy of Prematurity Revisited" by Gole et al. ${ }^{(18)}$ 


\begin{tabular}{|c|c|c|c|c|c|c|}
\hline No & Article & Author & Journal & PY & TC & AC \\
\hline 1 & $\begin{array}{l}\text { The international classification of retinopathy of prematurity } \\
\text { revisited }\end{array}$ & Gole et al. & $\begin{array}{l}\text { Archives of } \\
\text { Ophthalmology }\end{array}$ & 2005 & 1217 & 76.06 \\
\hline 2 & $\begin{array}{l}\text { Vascular endothelial growth factor acts as a survival factor } \\
\text { for newly formed retinal vessels and has implications for } \\
\text { retinopathy of prematurity }\end{array}$ & Alon et al. & Nature Medicine & 1995 & 1198 & 46.08 \\
\hline 3 & $\begin{array}{l}\text { Revised indications for the treatment of retinopathy of } \\
\text { prematurity: results of the early treatment for retinopathy of } \\
\text { prematurity randomized trial }\end{array}$ & Good et al. & $\begin{array}{l}\text { Archives of } \\
\text { Ophthalmology }\end{array}$ & 2003 & 953 & 52.94 \\
\hline 4 & An international classification of retinopathy of prematurity & Garner et al. & $\begin{array}{l}\text { Archives of } \\
\text { Ophthalmology }\end{array}$ & 1984 & 756 & 20.43 \\
\hline 5 & $\begin{array}{l}\text { Efficacy of intravitreal bevacizumab for stage } 3+\text { retinopathy } \\
\text { of prematurity }\end{array}$ & Mintz-Hittner, et al. & $\begin{array}{l}\text { New England Journal } \\
\text { of Medicine }\end{array}$ & 2011 & 572 & 57.2 \\
\hline 6 & $\begin{array}{l}\text { Multicenter trial of cryotherapy for retinopathy of } \\
\text { prematurity -preliminary results }\end{array}$ & Palmer et al. & $\begin{array}{l}\text { Archives of } \\
\text { Ophthalmology }\end{array}$ & 1988 & 465 & 14.09 \\
\hline 7 & Incidence and early course of retinopathy of prematurity & Palmer et al. & Ophthalmology & 1991 & 442 & 14.73 \\
\hline 8 & $\begin{array}{l}\text { Supplemental therapeutic oxygen for prethreshold } \\
\text { retinopathy of prematurity (STOP-ROP), a randomized, } \\
\text { controlled trial. I: primary outcomes }\end{array}$ & Phelps et al. & Pediatrics & 2000 & 405 & 19.29 \\
\hline 9 & $\begin{array}{l}\text { Characteristics of infants with severe retinopathy of } \\
\text { prematurity in countries with low, moderate, and high levels } \\
\text { of development: implications for screening programs }\end{array}$ & Gilbert et al. & Pediatrics & 2005 & 375 & 23.44 \\
\hline 10 & $\begin{array}{l}\text { Low IGF-I suppresses VEGF-survival signaling in retinal } \\
\text { endothelial cells: direct correlation with clinical retinopathy } \\
\text { of prematurity }\end{array}$ & Hellstrom et al. & $\begin{array}{l}\text { Proceedings of The } \\
\text { National Academy of } \\
\text { Sciences of the United } \\
\text { States of America }\end{array}$ & 2001 & 357 & 17.85 \\
\hline 11 & $\begin{array}{l}\text { Regulation of vascular endothelial growth factor by oxygen } \\
\text { in a model of retinopathy of prematurity }\end{array}$ & Pierce et al. & $\begin{array}{l}\text { Archives of } \\
\text { Ophthalmology }\end{array}$ & 1996 & 335 & 13.4 \\
\hline 12 & $\begin{array}{l}\text { Retinopathy of prematurity: a global perspective of the } \\
\text { epidemics, population of babies at risk and implications for } \\
\text { control }\end{array}$ & Gilbert et al. & $\begin{array}{l}\text { Early Human } \\
\text { Development }\end{array}$ & 2008 & 324 & 24.92 \\
\hline 13 & $\begin{array}{l}\text { Screening examination of premature infants for retinopathy } \\
\text { of prematurity }\end{array}$ & Lichtenstein et al. & Pediatrics & 2006 & 316 & 21.07 \\
\hline 14 & $\begin{array}{l}\text { Screening examination of premature infants for retinopathy } \\
\text { of prematurity }\end{array}$ & $\begin{array}{l}\text { Fierson, Walter et } \\
\text { al. }\end{array}$ & Pediatrics & 2013 & 298 & 37.25 \\
\hline 15 & $\begin{array}{l}\text { Can changes in clinical practice decrease the incidence of } \\
\text { severe retinopathy of prematurity in very low birth weight } \\
\text { infants? }\end{array}$ & Chow et al. & Pediatrics & 2003 & 298 & 16.56 \\
\hline 16 & $\begin{array}{l}\text { Postnatal serum insulin-like growth factor I deficiency } \\
\text { is associated with retinopathy of prematurity and other } \\
\text { complications of premature birth }\end{array}$ & Hellstrom et al. & Pediatrics & 2003 & 297 & 16.5 \\
\hline 17 & $\begin{array}{l}\text { The incidence and course of retinopathy of prematurity: } \\
\text { findings from the early treatment for retinopathy of } \\
\text { prematurity study }\end{array}$ & Good et al. & Pediatrics & 2005 & 265 & 16.56 \\
\hline 18 & Retinopathy of prematurity in middle-income countries & Gilbert C & Lancet & 1997 & 252 & 10.5 \\
\hline 19 & Retinopathy of prematurity & Hellstrom Ann & Lancet & 2013 & 250 & 31.25 \\
\hline 20 & $\begin{array}{l}\text { Roles of vascular endothelial growth factor and astrocyte } \\
\text { degeneration in the genesis of retinopathy of prematurity }\end{array}$ & Stone J & $\begin{array}{l}\text { Investigative } \\
\text { Ophthalmology \& } \\
\text { Visual Science }\end{array}$ & 1996 & 235 & 9.4 \\
\hline
\end{tabular}




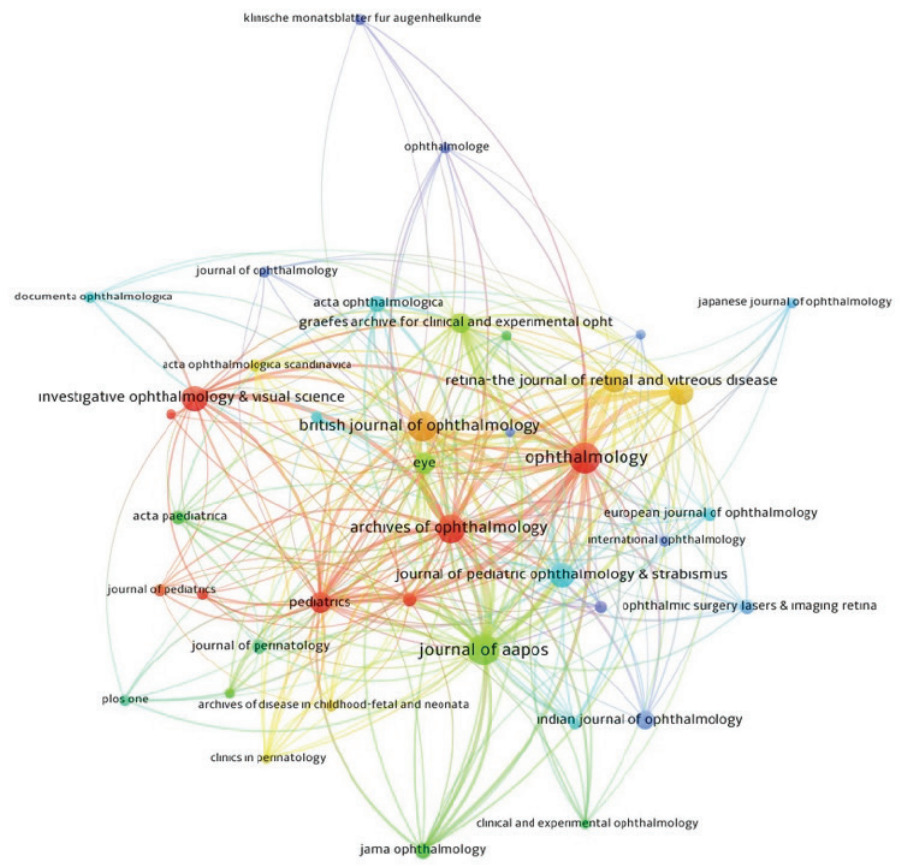

A vosviewer

Figure 4. Network visualization map for citation analysis of active journals on the topic of retinopathy of prematurity. Footnote: The number of average citations from blue to red (blue-green-yellow-red) increases. The size of the circle shows the large number of publications. The thickness of the lines indicates the strength of citation collaboration

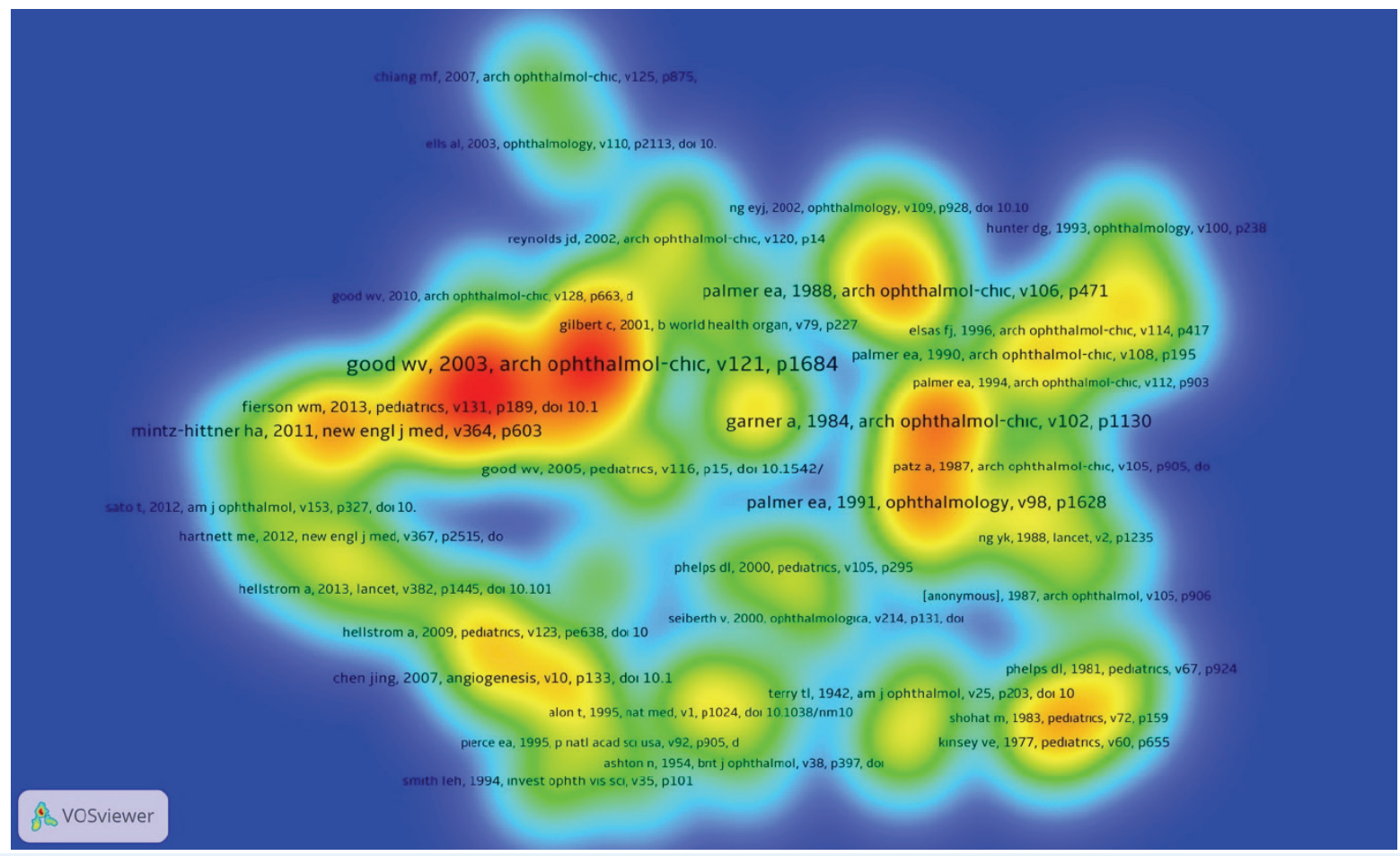

Figure 5. Density visualization map for cocitation analysis for articles on the topic of retinopathy of prematurity. Footnote: The number of citations from blue to red (blue-green-yellow-red) increases 


\begin{tabular}{|c|c|c|c|c|c|c|c|}
\hline Keyword & 0 & Keyword & 0 & Keyword & 0 & Keyword & 0 \\
\hline $\begin{array}{l}\text { Retinopathy of } \\
\text { prematurity }\end{array}$ & 823 & Infant & 25 & Pain & 15 & Oxygen therapy & 9 \\
\hline Prematurity & 108 & Telemedicine & 25 & Plus disease & 15 & Prevalence & 9 \\
\hline Risk factors & 77 & $\begin{array}{l}\text { Aggressive posterior } \\
\text { retinopathy of prematurity }\end{array}$ & 24 & Anti-VEGF & 14 & Retinal neovascularization & 9 \\
\hline Screening & 63 & Angiogenesis & 24 & Neonate & 14 & Visual acuity & 9 \\
\hline ROP & 60 & Low birth weight & 23 & Vitrectomy & 14 & Extremely low birth weight & 8 \\
\hline Bevacizumab & 57 & Premature infant & 23 & Laser therapy & 12 & Fluorescein angiography & 8 \\
\hline $\begin{array}{l}\text { Vascular endothelial } \\
\text { growth factor }\end{array}$ & 53 & Laser & 22 & Laser treatment & 12 & Hyperglycemia & 8 \\
\hline Retinopathy & 50 & Neovascularization & 22 & Very low birth weight & 12 & Neonatal intensive care & 8 \\
\hline $\begin{array}{l}\text { Retınopathy of } \\
\text { prematurıty }\end{array}$ & 47 & Retinal detachment & 21 & $\begin{array}{l}\text { Bronchopulmonary } \\
\text { dysplasia }\end{array}$ & 11 & Newborn & 8 \\
\hline Preterm infant & 45 & Myopia & 20 & Diode laser & 11 & Pediatric ophthalmology & 8 \\
\hline Gestational age & 44 & Blindness & 19 & IGF-I & 11 & Photocoagulation & 8 \\
\hline $\begin{array}{l}\text { Laser } \\
\text { photocoagulation }\end{array}$ & 40 & Oxygen & 19 & Intravitreal injection & 11 & Propranolol & 8 \\
\hline Birth weight & 39 & Premature & 19 & $\begin{array}{l}\text { Optical coherence } \\
\text { tomography }\end{array}$ & 11 & Sepsis & 8 \\
\hline Ranibizumab & 33 & Oxygen-induced retinopathy & 18 & Erythropoietin & 10 & Strabismus & 8 \\
\hline Cryotherapy & 32 & VEGF & 18 & Polymorphism & 10 & & \\
\hline Retina & 29 & Preterm & 16 & Childhood blindness & 9 & & \\
\hline Incidence & 25 & Treatment & 16 & Epidemiology & 9 & & \\
\hline
\end{tabular}

published in the Archives of Ophthalmology, followed by "Vascular Endothelial Growth Factor Acts as a Survival Factor for Newly Formed Retinal Vessels and Has Implications for Retinopathy of Prematurity" by Alon et al. (19) published in Nature Medicine. Apart from these studies, other effective studies according to the mean number of citations were "Efficacy of Intravitreal Bevacizumab for Stage 3+ Retinopathy of Prematurity" by Mintz-Hittner HA (2011) and "Revised Indications for the Treatment of Retinopathy of Prematurity-Results of the Early Treatment for Retinopathy of Prematurity Randomized Trial" by Good et al. (17) (Early Treatment For Retinopathy of Prematurity Cooperative Group) ${ }^{(20)}$. It is recommended that researchers working on this subject read the previously mentioned articles and other articles on the list.

Based on the keyword analysis, it was observed that subjects such as epidemiology, optical coherence tomography, aggressive posterior ROP, ranibizumab, telemedicine, polymorphism, pain, and screening were studied more in the past, whereas recently, subjects such as laser therapy, oxygen-induced retinopathy, oxygen therapy, angiogenesis, anti-VEGF, birth weight, GA, prevalence, and incidence have emerged. The keywords receiving the most citations were determined to be preterm infants, bronchopulmonary dysplasia, oxygen therapy, very low birth weight, incidence, erythropoietin, visual acuity, and strabismus.

No bibliometric study on ROP was found in the literature. Paras et al. (2017) analyzed a 40-year period of literature (1976-2015) on ROP. The focus of that study was only on countries producing the most publications and levels of development of those countries, journals publishing the most publications, and distribution of publications by year ${ }^{211}$. The current study is much more comprehensive than the previously mentioned study. In addition to the information provided in the previous study, keyword analyses and trend subjects were determined in the current study, and by creating network maps, important articles and journals were revealed. 


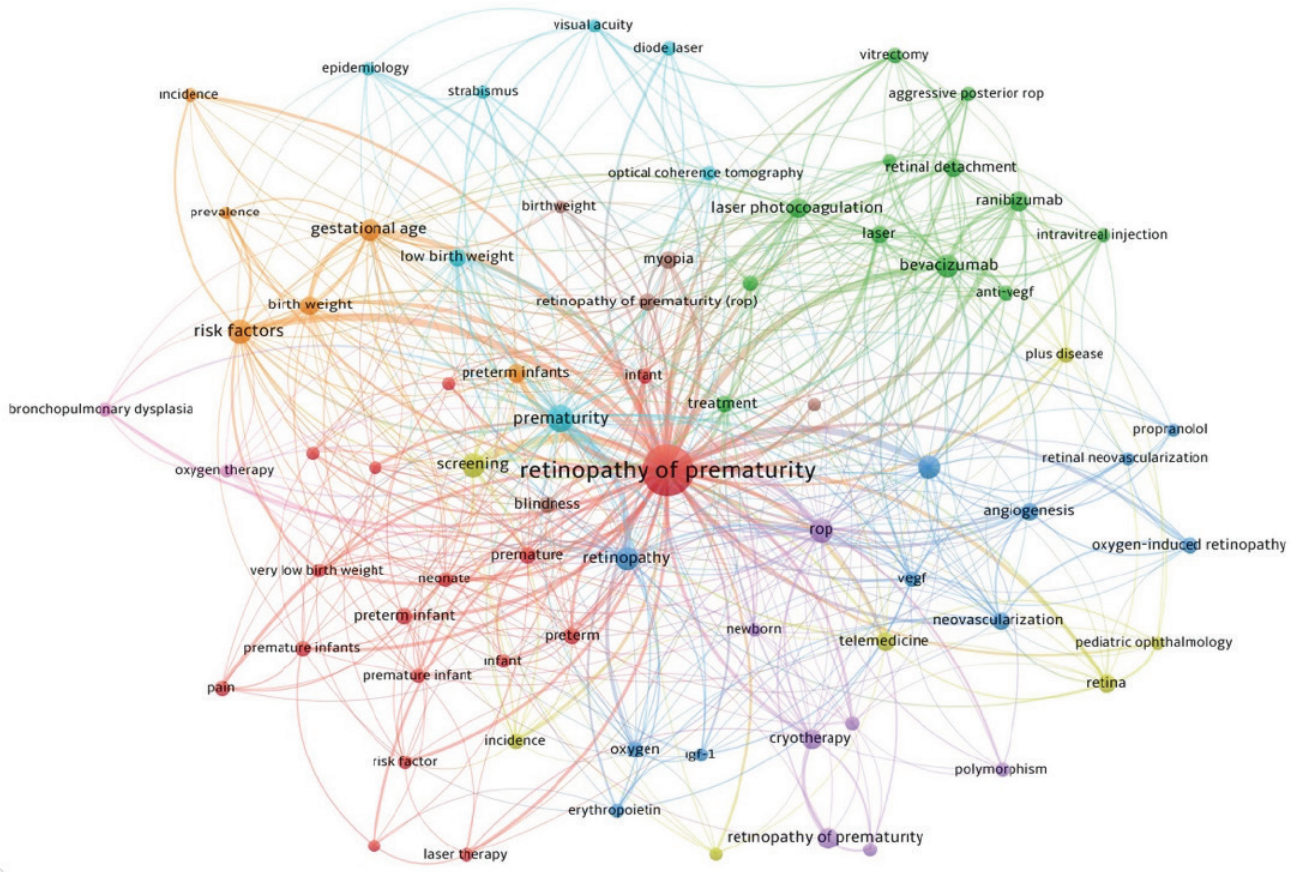

A vosviewer

Figure 6. Network visualization cluster map for keyword analysis on the topic of retinopathy of prematurity. Footnote: Six colors show the clustering between the keywords. The size of the circles indicates that the keyword is used frequently. The thickness of the lines indicates the strength of relationship

B vosviewer

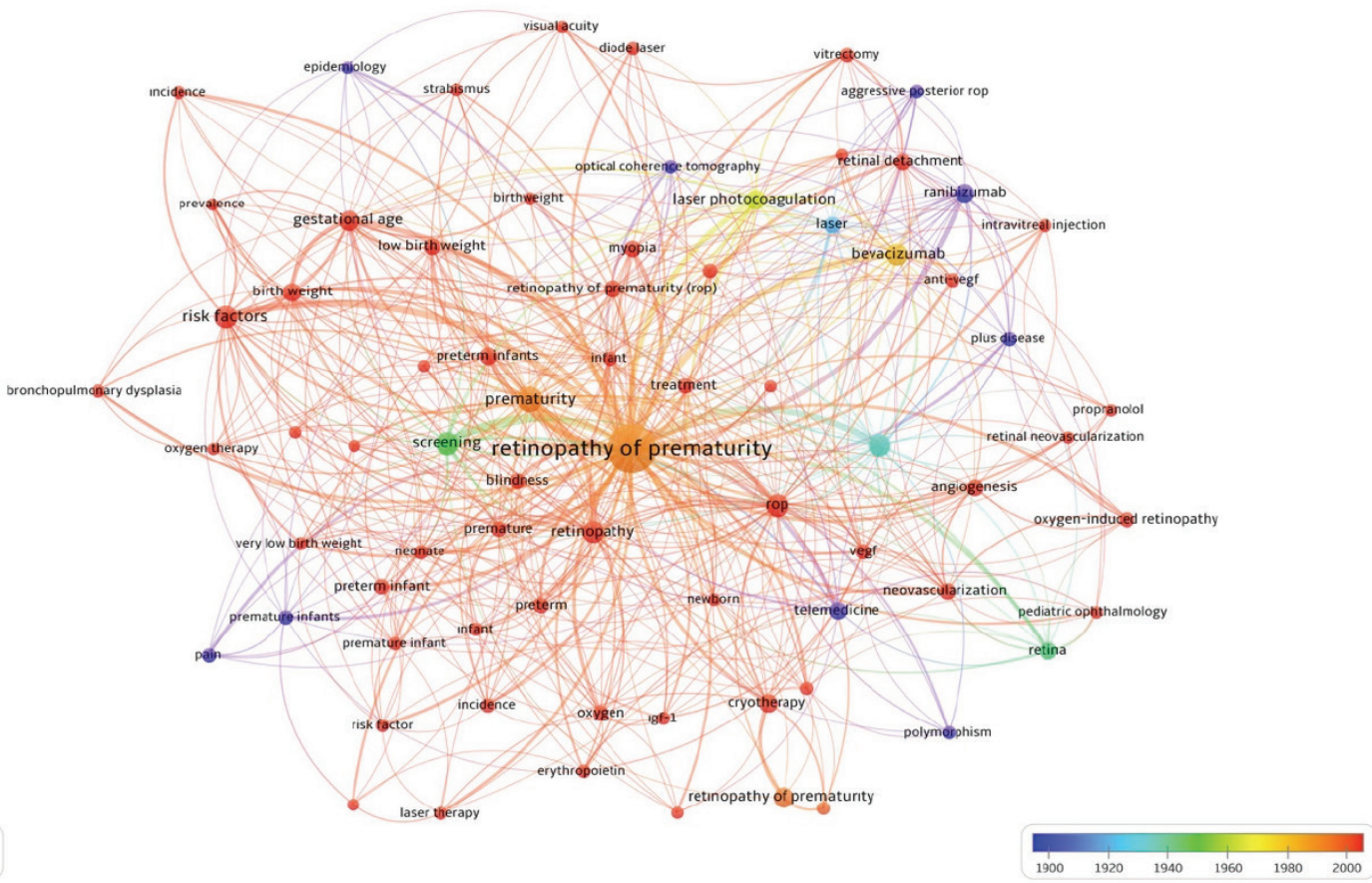

Figure 7. Network visualization map for trends based on keyword analysis on the topic of retinopathy of prematurity. Footnote: The number of uses of the keyword increases from blue to red (blue-green-yellow-red). The size of the circles indicates that the keyword is used frequently. The thickness of the lines indicates the strength of relationship 


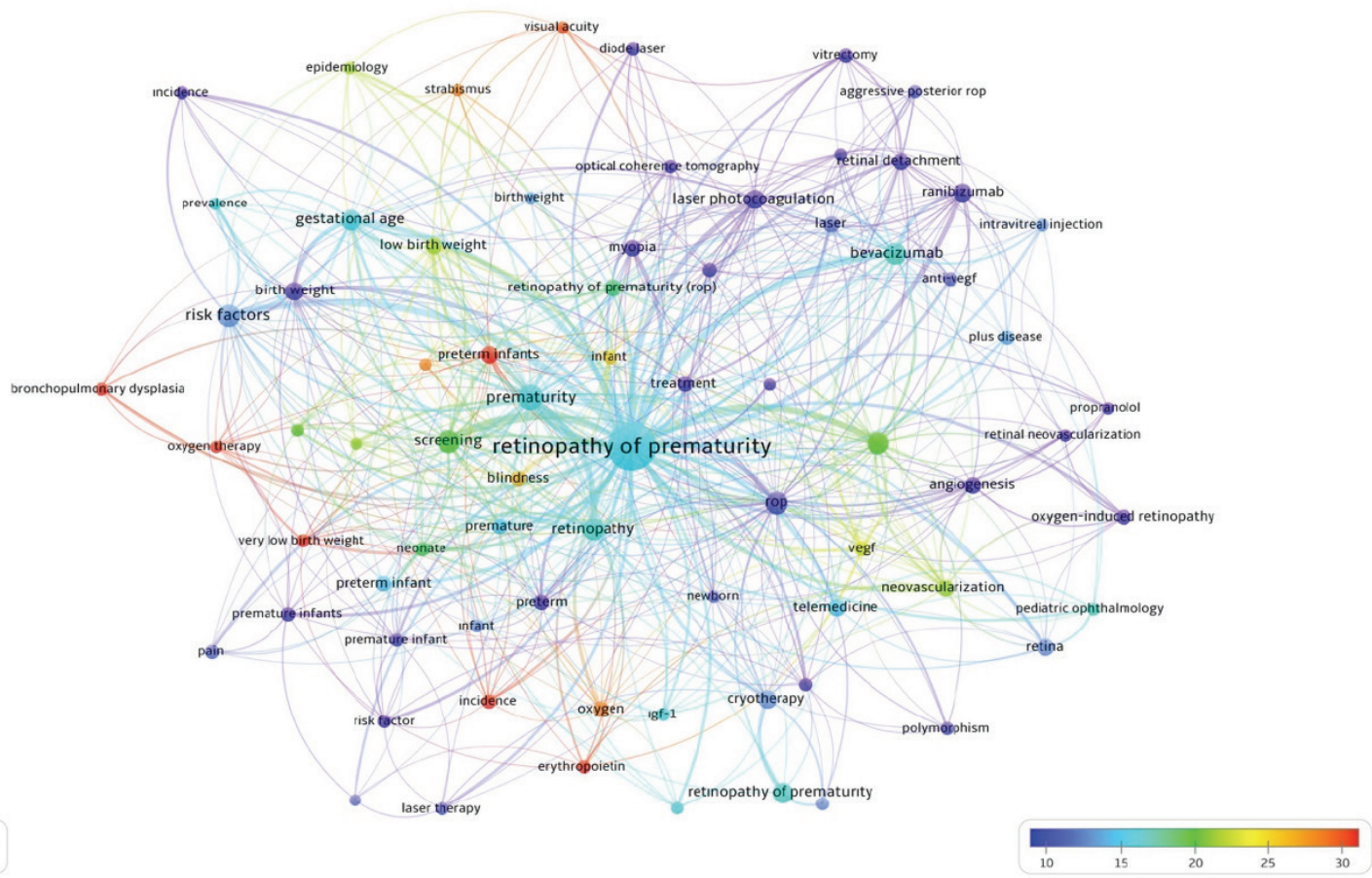

Figure 8. Network visualization map for the most cited keyword on the topic of retinopathy of prematurity. Footnote: The number of citations received by the keyword increases from blue to red (blue-green-yellow-red). The size of the circles indicates that the keyword is used frequently. The thickness of the lines indicates the strength of relationship

\section{Study Limitations}

A potential limitation of the current study is that the literature search was made only using the WoS Index. However, in recent literature, only WoS has been widely used in bibliometric studies ${ }^{(10,11-16,22)}$ because WoS is a more reliable index than other databases for journals scanned and quotations. The impact factor of all journals indexed in WoS is high.

\section{CONCLUSION}

In parallel with the increasing importance of ROP, this comprehensive study, which holistically evaluated articles in this field, will be of guidance to clinicians, academicians, and students interested in this subject. Additionally, the study results will provide new ideas to researchers planning a new research on this subject. The productivity of ROP research was closely related to the economic strength and level of development of the country. However, the finding that some developing countries, such as Turkey, were among the most productive countries is explained by the increase in research productivity parallel to the increased number of patients with ROP, as a result of investment in NICU throughout the country.
Ethics Committee Approval: This article does not contain any studies with human participants or animals performed by any of the authors.

Informed Consent: For this type of study formal consent is not required.

Financial Disclosure: The authors declared that this study received no financial support.

Etik Kurul Onayı: Bu makale, yazarlardan herhangi biri tarafından gerçekleștirilen insan katıımcıları veya hayvanlarla yapılan herhangi bir çalıșmayı içermemektedir.

Hasta Onayı: Bu tür bir çalışma için resmi izin gerekli değildir.

Finansal Destek: Yazarlar tarafından finansal destek almadıkları bildirilmiştir.

\section{REFERENCES}

1. Shah PK, Prabhu V, Karandikar SS, Ranjan R, Narendran V, Kalpana N. Retinopathy of prematurity: Past, present and future. World J Clin Pediatr. 2016;5:35-46. doi: 10.5409/wjcp.v5.i1.35..

2. Gilbert C. Retinopathy of prematurity: a global perspective of the epidemics, population of babies at risk and implications for control. Early Hum Dev 2008;84:77-82. doi: 10.1016/j.earlhumdev.2007.11.009 
3. Hellström A, Smith LE, Dammann O. Retinopathy of prematurity. Lancet. 2013;382:1445-57. doi: 10.1016/S0140-6736(13)60178-6

4. Caglar C, Demir E, Kucukler FK, Durmus M. A bibliometric analysis of academic publication on diabetic retinopathy disease trends during 1980-2014: a global and medical view. Int J Ophthalmol. 2016;9:16638. doi: 10.18240/ijo.2016.11.21.

5. Sancak S, Topçuoğlu S, Çelik G, Günay M, Karatekin G. Evaluation of the incidence and risk factors of retinopathy of prematurity. Zeynep Kamil Med J. 2019;50:63-8. doi: 10.16948/zktipb.474762.

6. Bas AY, Demirel N, Koc E, Ulubas Isik D, Hirfanoglu IM, Tunc T; TRROP Study Group. Incidence, risk factors and severity of retinopathy of prematurity in Turkey (TR-ROP study): a prospective, multicentre study in 69 neonatal intensive care units. $\mathrm{Br} \mathrm{J}$ Ophthalmol. 2018;102:1711-6. doi: 10.1136/bjophthalmol-2017-311789.

7. Eriş E, Perente I, Seymen Z, Aslı Vural, Erdoğan G, Onur U, et al. Assessment of frequency and major risk factors of retinopathy in prematures between years 2015 and 2016. Medical Journal of Bakirkoy. 2016;14:204-8. doi: 10.5350/BTDMJB.20170615063850

8. Austeng $D$, Källen KB, Ewald UW, Jakobsson PG, Holmström GE. Incidence of retinopathy of prematurity in infants born before 27 weeks' gestation in Sweden. Arch Ophthalmol. 2009;127:1315-9. doi: 10.1001/archophthalmol.2009.244

9. Weber $C$, Weninger $M$, Klebermass $K$, Reiter $G$, Wiesinger-Eidenberger $\mathrm{G}$, Brandauer M, et al. Mortality and morbidity in extremely preterm infants (22 to 26 weeks of gestation): Austria 1999-2001. Wien Klin Wochenschr. 2005;117:740-6. doi: 10.1007/s00508-005-0468-y.

10. Demir E, Comba A. The evolution of celiac disease publications: a holistic approach with bibliometric analysis. Ir J Med Sci. 2020;189:267-76. doi: 10.1007/s11845-019-02080-x.

11. Demir E. The evolution of spirituality, religion and health publications: yesterday, today and tomorrow. J Relig Health. 2019;58:1-13. doi:10.1007/s10943-018-00739-w.

12. Doğan G, Kayır S. Global scientific outputs of brain death publications and evaluation according to the religions of countries. J Relig Health. 2020;59:96-112. doi: 10.1007/s10943-019-00886-8.

13. Demir E, Yașar E, Özkoçak V, Yıldııım E. The evolution of the field of legal medicine: a holistic investigation of global outputs with bibliometric analysis. J Forensic Leg Med. 2020;69:101885. doi: 10.1016/j.jflm.2019.101885

14. Doğan G, İpek H. The development of necrotizing enterocolitis publications: a holistic evolution of global literature with bibliometric analysis. Eur J Pediatr Surg. 2020;30:293-303. doi: 10.1055/s-00393400514.

15. Yıldırım E, Demir E. Comparative bibliometric analysis of fertility preservation. Ann Med Res. 2019;26:1622-8. doi: 10.5455/ annalsmedres.2019.06.339

16. Ozsoy Z, Demir E. The evolution of bariatric surgery publications and global productivity: a bibliometric analysis. Obes Surg 2018;28:111729. doi: 10.1007/s11695-017-2982-1.

17. Early Treatment For Retinopathy of Prematurity Cooperative Group. Revised indications for the treatment of retinopathy of prematurity: results of the early treatment for retinopathy of prematurity randomized trial. Arch Ophthalmol. 2003;121:1684-94. doi: 10.1001/ archopht.121.12.1684.

18. International Committee for the Classification of Retinopathy of Prematurity. The International Classification of Retinopathy of Prematurity revisited. Arch Ophthalmol. 2005;123:991-9. doi: 10.1001/ archopht.123.7.991.

19. Palmer EA, Flynn JT, Hardy RJ, Phelps DL, Phillips CL, Schaffer DB, et al. Incidence and early course of retinopathy of prematurity. The Cryotherapy for Retinopathy of Prematurity Cooperative Group. Ophthalmology. 1991;98:1628-40. doi: 10.1016/s0161-6420(91)320748.

20. Alon T, Hemo I, Itin A, Pe'er J, Stone J, Keshet E. Vascular endothelial growth factor acts as a survival factor for newly formed retinal vessels and has implications for retinopathy of prematurity. Nat Med. 1995;1:1024-8. doi: 10.1038/nm1095-1024.

21. Mintz-Hittner HA, Kennedy KA, Chuang AZ. Efficacy of intravitreal bevacizumab for stage 3+ retinopathy of prematurity. N Eng J Med. 2011;364:603-15. doi: 10.1056/NEJMoal007374

22. Ozsoy Z, Demir E. Which bariatric procedure is the most popular in the world? A bibliometric comparison. Obes Surg. 2018;28:2339-52. doi: 10.1007/s11695-018-3163-6. 